\title{
Effects of dietary 20-hydroxyecdysone supplementation on whole-body protein turnover in growing pigs
}

\author{
Olga Obvintseva ${ }^{1}$, Kenes Erimbetov ${ }^{1, *}$, Vitaly Mikhailov ${ }^{2}$ \\ ${ }^{1}$ L.K. Ernst Federal Science Center for Animal Husbandry - All-Russian Research Institute of Animal \\ Physiology, Biochemistry, and Nutrition, Institute village, 249013, Borovsk, Kaluga Region, Russia \\ ${ }^{2}$ Tambov State University named after G.R. Derzhavina, st. International, 33, 392024, Tambov, \\ Russia
}

\begin{abstract}
One of the approaches to creating biologically active additives for use in pig breeding can be the use of 20-hydroxyecdysone regulating protein metabolism in piglets. The purpose of the work is to assess the effect of 20-hydroxyecdysone on turnover of protein in piglets. The experiment was carried out on barrows ( $\delta$ Danish Yorkshire $\times 9$ Danish landrace) to achieve a live weight of 53-62 kg. At the age of 60 days, 2 groups of piglets were formed: control and experimental. Piglets of the experimental group were injected with 20-hydroxyecdysone at a dose of $1.6 \mathrm{mg} / \mathrm{kg}$ body weight. In piglets of the experimental group, in comparison with the control, a decrease in the excretion of nitrogen in the urine was noted (by 26.8\%, $\mathrm{P}<0.05$ ). Nitrogen deposition was higher in piglets of the experimental group by $19.0 \%(\mathrm{P}<0.001)$ compared with the control. 20-hydroxyecdysone contributed to increased protein deposition in the body of piglets due to protein synthesizing activity. Thus, the use of 20-hydroxyecdysone in pigs increases the efficiency of using amino acids for the synthesis and deposition of proteins in the body.
\end{abstract}

\section{Introduction}

The processes of protein metabolism in the body of growing animals largely depend on nutritional conditions, content, intensity of their cultivation and other factors. Of particular interest are studies on the characteristics of protein metabolism in the body of intensively growing animals in connection with the different supply of amino acids and biologically active substances. The limited knowledge of the mechanisms of regulation of the synthesis and deposition of proteins in the body hinders the development of methods, tools and technologies that contribute to the maximum manifestation of the genetic potential of pig meat productivity, including the production of high-quality pork with a certain ratio of fat and protein in meat $[1,2,3,4]$.

Optimization of nutritional conditions adequate to the physiological needs of pigs contributes to a more complete realization of the productive potential with minimal feed costs per unit of production. An urgent problem in pig breeding is the development of

\footnotetext{
${ }^{*}$ Corresponding author: erimbetovkt@mail.ru
} 
complete feed with the optimal content of protein, energy and essential amino acids. Of great importance is the use of additives of biologically active substances, including phytobiotics, which allow to obtain high average daily gains in live weight, increase the efficiency of feed bioconversion per unit of production and meat quality [5].

One of the approaches to creating a new generation of biologically active additives for use in animal husbandry can be the use of herbal remedies that increase the resistance and adaptive ability of animals. Of particular interest in this regard are plant sources of phytoecdysteroids - polyhydroxylated sterols that do not have a hormonal effect in mammals and have low toxicity. One of the most widely studied phytoecdysteroids is 20hydroxyecdysone, which is part of some types of medicinal plants. The empirical, structural formulas and molecular weight of 20-hydroxyecdysone are presented below:

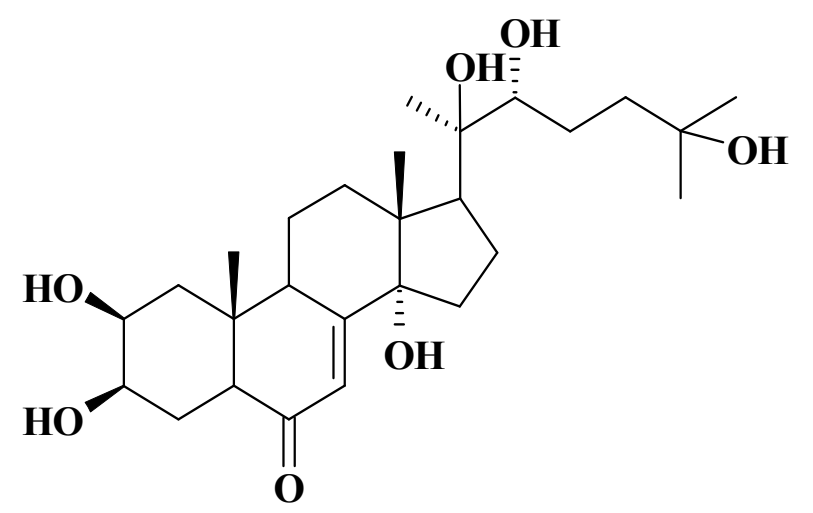

Fig. 1. Empirical formula: $\mathrm{C}_{27} \mathrm{H}_{44} \mathrm{O}_{7}$, Molecular Weight: 480.64 .

The multiplicity of physiological effects in combination with the low toxicity of 20hydroxyecdysone makes it possible to use it both as an individual compound and as a part of combined preparations. In recent years, great progress has been noted in the study of phytoecdysteroids, their physiological actions in various pathologies and the corrective properties in relation to metabolism in the body have been intensively studied $[6,7,8,9$, 10,11]. According to studies [12], 20-hydroxyecdysone enhances protein synthesis by activating signals through PKB / Akt (protein kinase B / Akt kinase (RAC-alpha serine / threonine protein kinase) to the target of the rapamycin 1 complex (mTORC1).

\section{Purpose of the study}

The aim of this study was to evaluate the effect of 20 -hydroxyecdysone on body protein metabolism and measure their turnover in growing pigs.

\section{Materials and methods}

The experiment was carried out on cross-border piglets, boars ( $\delta$ Danish Yorkshire $\times q$ Danish landrace). According to the principle of paired analogues taking into account live weight, at the age of 60 days, 2 groups of piglets were formed, fed 2 times a day $(9.00$ and 16.00) throughout the entire experiment. Group content in the cells, drinking from the car drinkers. The experiment lasted until the live weight of piglets $53-62 \mathrm{~kg}$. Animals of the control and experimental groups received a feed during the growing period, $1 \mathrm{~kg}$ of which contained crude protein $158.7 \mathrm{~g}$, lysine $7.7 \mathrm{~g}$, threonine $4.8 \mathrm{~g}$, methionine 4.6 $\mathrm{g}$, metabolic energy 12.7 MJ The ratio of lysine to exchange energy was $61 \%$ (g/MJ). The 
diet of piglets of the experimental group was injected with the drug 20-hydroxyecdysone (dry powder) at a rate of $30 \mathrm{mg} / \mathrm{kg}$ of feed (table. 1). The dose of 20-hydroxyecdysone per unit body weight was $1.6 \mathrm{mg} / \mathrm{kg}$. Throughout the experiment, the consumption of compound feed, its chemical composition and consumption per unit of growth were recorded. Piglets were weighed at the beginning of the experiment and at the end of the age period. To characterize the assimilation of nitrogen in feeds and evaluate the effectiveness of their use, we carried out a balance experiment at the end of the growing period in 7 animals ( $\mathrm{n}=3$ in the control group and 4 in the experimental group). After carrying out the balance experiment, we carried out the slaughter of all 7 animals, followed by deboning the carcasses to determine the slaughter qualities and taking samples of organs and tissues for physiological and biochemical studies.

Table 1. Ingredient composition of the basal diet.

\begin{tabular}{|c|c|}
\hline Ingredients & Composition, \% (as-fed basis) \\
\hline Barley & 48.6 \\
\hline Wheat & 20.0 \\
\hline Corn & 10.0 \\
\hline Soybean meal & 12.0 \\
\hline Sunflower meal & 6.0 \\
\hline L-Lysine $\cdot \mathrm{HCl}$ & 0.33 \\
\hline DL-methionine & 0.03 \\
\hline Salt & 0.4 \\
\hline Monocalcium phosphate & 0.8 \\
\hline Lime flour & 1.2 \\
\hline Premix KS-4 & 1.0 \\
\hline 20-hydroxyecdysone ${ }^{\mathrm{a}}$ & - \\
\hline \multicolumn{2}{|l|}{ In $1 \mathrm{~kg}$ of feed contains: } \\
\hline Metabolic energy, MJ & 12.7 \\
\hline Crude protein, $\mathrm{g}$ & 158.7 \\
\hline Digestible protein, $g$ & 130 \\
\hline Lysine, $\mathrm{g}$ & 7.7 \\
\hline Threonine, $g$ & 5.0 \\
\hline Methionine + cystine, $g$ & 4.8 \\
\hline
\end{tabular}

Where: ${ }^{a}$ In the 20-hydroxyecdysone -supplemented diets, $1.6 \mathrm{mg} / \mathrm{kg}$ was added at the expense of corn.

Most studies use the nitrogen metabolism model to measure protein turnover in the whole body [13], which is based on measuring the kinetics of metabolism of the introduced marker. To measure the rate of protein synthesis using this model, the total precursor flux, the rate of formation of the final products of nitrogen metabolism, and the rate of precursor secretion from the total fund into the gastrointestinal tract must be known. Methodological aspects of measuring the rates of protein synthesis and decomposition in the whole body using ${ }^{15} \mathrm{~N}$ amino acids are considered in detail in [13]. The results obtained by the researchers indicate that the use of different amino acids gives comparable data, despite the fact that the specificity of these amino acids as precursors for protein synthesis is not the same.

During the balance experiment, the rate of synthesis, decomposition, and deposition of total body proteins was determined in piglets at the end of the growing period according to the method [13] using labeled amino acid for nitrogen ${ }^{15} \mathrm{~N}$-glycine. ${ }^{15} \mathrm{~N}$-glycine with an enrichment of $98 \%$ atomic excess was administered per os in the amount of $3 \mathrm{mg}{ }^{15} \mathrm{~N}$ per 1 $\mathrm{kg}$ of animal body weight for 7 days. Stool and urine samples for isotope analysis were taken in a separate trial with a daily interval in compliance with all requirements for working with stable isotopes. Feces collected during the $\mathrm{N}$ balance period were pooled, 
freeze-dried and stored at $4{ }^{\circ} \mathrm{C}$ for $\mathrm{N}$ determination. Urine collected was stored at $-20{ }^{\circ} \mathrm{C}$ until analysis for N. Samples of diet, urine and feces were analyzed for $\mathrm{N}$ content by Kjeldahl method [14]. The N-retention was calculated by minus $\mathrm{N}$ excretion (via feces and urine) from $\mathrm{N}$ intake. For isotopic studies from feces, urine taken on the 6th day of the balance experiment, nitrogen fractions were preparatively isolated using a Kjeltek instrument using the Kjeldahl method [14] with washing the system with ethyl alcohol to isolate each sample. The ${ }^{15} \mathrm{~N}$ content (in atomic percent) was measured on a DELTA V Plus isotope mass spectrometer.

The rates of synthesis, decomposition and deposition of proteins in the whole organism were calculated using the following formulas (1), (2), (3):

$$
\begin{gathered}
\mathrm{V} 1=\mathrm{WF} \times \mathrm{NF}-\mathrm{NO} / \mathrm{NM}-\mathrm{NO}-\mathrm{WM}-\mathrm{WK} \times \mathrm{NK}-\mathrm{NO} / \mathrm{NM}-\mathrm{NO} \\
(\mathrm{g} \text { atom. } \mathrm{N} / \text { day } \times 14 \times 6.25) \\
\mathrm{V} 2=\mathrm{V} 1+\mathrm{WM}+\mathrm{WK}-\mathrm{WF} \\
\mathrm{V} 3=\mathrm{V} 1-\mathrm{V} 2
\end{gathered}
$$

Where V1 - protein synthesis, g / day; WF - taken nitrogen with feed, g / day; NF taken ${ }^{15} \mathrm{~N}$ with food; NO - natural enrichment (background, atomic percentage of excess); $\mathrm{NM}-\left({ }^{15} \mathrm{~N}\right)$ atomic percentage of excess in urine; $\mathrm{NK}-\left({ }^{15} \mathrm{~N}\right)$ atomic percentage of excess in feces; WM - nitrogen excreted in urine g / day; WK - nitrogen excreted with feces, g / day; V2 - protein breakdown, g / day; V3 - protein deposition, g / day.

The data for all parameters determined were analyzed statistically by one-way ANOVA of SPSS 11.0 software. A value of $p<0.05$ was considered statistically significant. Data are presented as means \pm standard error of the mean (SEM).

\section{Results of study and its discussion}

The results of physiological studies on the nitrogen balance showed that feeding 20hydroxyecdysone to pigs as part of a feed helps to more efficient use of nitrogenous feed substances compared to the control. In piglets of the experimental group, compared with the control, a decrease in the excretion of nitrogen in the urine (by $26.8 \%, \mathrm{P}<0.05$ ) was observed against the background of the same digestibility of the feed protein (Table 2). In the final outcome, nitrogen deposition was $19.0 \%$ higher $(\mathrm{P}<0.001)$ in piglets of the experimental group compared to the control. At the same time, the use of nitrogen from both accepted and overcooked was higher in piglets of the experimental group.

Table 2. Effects of 20-hydroxyecdysone supplementation on nitrogen balance (SEM).

\begin{tabular}{|l|c|c|}
\hline \multirow{2}{*}{\multicolumn{1}{|c|}{ Items }} & \multicolumn{2}{c|}{ 20-hydroxyecdysone, $\mathbf{~ m g / k g}$} \\
\cline { 2 - 3 } & $\mathbf{0}$ & $\mathbf{1 . 6}$ \\
\hline Nitrogen intake $(\mathrm{g} / \mathrm{d})$ & $42.8 \pm 0.41$ & $42.4 \pm 0.14$ \\
\hline Nitrogen in feces (g/d) & $11.1 \pm 0.38$ & $11.0 \pm 0.23$ \\
\hline Nitrogen in urine (g/d) & $13.8 \pm 0.64$ & $10.1 \pm 0.32^{*}$ \\
\hline Nitrogen retention (g/d) & $17.9 \pm 0.11$ & $21.3 \pm 0.18^{* * *}$ \\
\hline Apparent nitrogen digestibility (\%) & $74.1 \pm 1.13$ & $74.0 \pm 0.94$ \\
\hline Nitrogen retention efficiency (\%) & $41.8 \pm 0.17$ & $50.2 \pm 0.67^{* * *}$ \\
\hline $\begin{array}{l}\text { Efficiency of digestible N } \\
\text { utilization (\%) }\end{array}$ & $56.4 \pm 1.11$ & $67.8 \pm 1.17^{* *}$ \\
\hline
\end{tabular}

Apparent nitrogen digestibility $=100 \% \times($ nitrogen intake nitrogen in feces $) /$ nitrogen intake. Nitrogen retention efficiency $=100 \% \times$ nitrogen retention/nitrogen intake. Efficiency of digestible $\mathrm{N}$ utilization $=100 \% \times$ nitrogen retention/(nitrogen intake nitrogen in feces). $\mathrm{n}=$ 
3 in the control group and 4 in the experimental group. * $\mathrm{P}<0.05 ; * * \mathrm{P}<0.01 * * * \mathrm{P}<0.001$ by the U-criterion when compared with 0 (control).

When studying the effect of 20-hydroxyecdysone on the intensity of body protein metabolism in piglets, a change in the ratio of synthesis and decay to an increase in biosynthetic processes was revealed. The intensity of the synthesis of body proteins was higher in piglets treated with 20-hydroxyecdysone in the diet compared to animals in the control group. It is characteristic that, along with an increase in the intensity of protein synthesis, there was also a certain increase in the rate of their decomposition, and, consequently, renewal with a relative predominance of biosynthetic processes. This state of protein metabolism led to an increase in their level in the body (protein stock) in piglets of the experimental group (Table 3 ).

Table 3. Effects of 20-hydroxyecdysone supplementation on protein turnover in growing pigs (SEM).

\begin{tabular}{|c|c|c|}
\hline \multirow{2}{*}{ Items } & \multicolumn{2}{|c|}{ 20-hydroxyecdysone, $\mathrm{mg} / \mathrm{kg}$} \\
\hline & $\mathbf{0}$ & 1.6 \\
\hline $\mathrm{S}\left(\mathrm{g} \mathrm{N} / \mathrm{kg} \mathrm{W}^{0.75} / \mathrm{d}\right)$ & $2.54 \pm 0.04$ & $2.77 \pm 0.06^{*}$ \\
\hline $\mathrm{B}\left(\mathrm{g} \mathrm{N} / \mathrm{kg} \mathrm{W}^{0.75} / \mathrm{d}\right)$ & $1.62 \pm 0.04$ & $1.74 \pm 0.04$ \\
\hline $\mathrm{NPG}\left(\mathrm{g} \mathrm{N} / \mathrm{kg} \mathrm{W} \mathrm{W}^{0.75} / \mathrm{d}\right)$ & $0.92 \pm 0.03$ & $1.03 \pm 0.02 * *$ \\
\hline $\mathrm{NF}\left(\mathrm{g} \mathrm{N} / \mathrm{kg} \mathrm{W}^{0.75} / \mathrm{d}\right)$ & $3.45 \pm 0.08$ & $4.00 \pm 0.09 * *$ \\
\hline EUN (g N/kg W0.75/d) & $0.71 \pm 0.05$ & $0.48 \pm 0.06 * *$ \\
\hline
\end{tabular}

Where: S - protein synthesis rate; B - protein breakdown rate; NPG - net protein gain expressed in nitrogen; NF - nitrogen flux; EUN - endogenous urinary nitrogen. W0.75 0.75 metabolic body weight. $\mathrm{n}=3$ in the control group and 4 in the experimental group. ${ }^{*} \mathrm{P}$ $<0.05$; ** $\mathrm{P}<0.02$ by the U-criterion when compared with 0 (control).

It was found that various plant steroid compounds, phytoecdysteroids, enhance protein synthesis and activate Akt signaling similarly to IGF-I in cultured myocytes [15]. It is believed that the anabolic adaptogenic effect of them, in particular 20-hydroxyecdysone, can be used in the nutrition of athletes [7]. In experiments on pigs, an increase in protein synthesis and deposition, muscle growth with the introduction of 20-hydroxyecdysone in the diet was found [16]. Feeding these and other phytoecdysteroids causes a decrease in obesity in mice $[11,16]$. However, recent feeding studies have failed to identify the distinct effects of 20-hydroxyecdysone on Akt or mTORC1 signaling in skeletal muscle [12]. This suggests that phytoecdysteroids may be involved in the regulation of long-term transcriptional changes in muscle protein breakdown, in contrast to the signaling mechanisms that regulate muscle protein synthesis $[11,12]$.

\section{Conclusion}

Dietary 20-hydroxyecdysone supplementation may improve growth performance in growing pigs. Protein deposition is increased after dietary 20-hydroxyecdysone supplementation. This increase is caused by an increase in the rate of protein synthesis.

\section{References}

1. A. Robina, J. Viguera, T. Perez-Palacios, A.I. Mayoral, J.M. Vivo, M.T. Guillen, Span J. Agric. Res. 11(4), 1057-1067 (2013)

2. V. Fuentes, S. Ventanas, J. Ventanas, M. Estevez, Meat Science 96(2), 737-743 (2014)

3. Y. Liu, X. Kong, G. Jiang, B. Tan, J. Deng, X. Yang, F. Li, X. Xiong, Y. Yin, J. Anim. Sci. Biotech. 6(36), 234-244 (2015) 
4. M. Ayuso, A. Fernández, Y. Núñez, R. Benítez and others, Plos One 22 (2015) DOI:10.1371/journal.pone.0145162

5. Y.H. Li, F.N. Li, Y.H. Duan, Q.P. Guo and others, J. Anim. Sci. 96(8), 3221-3232 (2018)

6. C.X. Luo, W.H. Chu, Y.A. Shan, Z.-M. Qian, J. Hu, PLoS ONE 7(12), e50764 (2012)

7. V.A. Volodin, Yu.S. Sidorova, V.K. Mazo, Voprosy pitaniya - Nutrition issues 82(6), 24-30 (2013)

8. R.N. Kumar, R. Sundaram, P. Shanthi, Eur. J. Pharmac. 698(1-3), 489- 498 (2013)

9. Q. Zhang, R. Liu, X. Xichao, European Journal of Pharmacology 740, 45-52 (2014)

10. X.R. Li, P.C. Liu, R. Jing, The Journal of Steroid Biochemistry and Molecular Biology 144(B), 313-323 (2014)

11. T.G. Anthony, Domest Anim Endocrinol 56, 23-32 (2016) 10.1016/j.domaniend.2016.02.012

12. T.G. Anthony, E.T. Mirek, A.R. Bargoud, and others, Appl Physiol. Nutr. Metabol. 40, 1324-1328 (2015)

13. J. B. Van Goudoever, D.E. Matthews, General Concepts of Protein Metabolism 1, 436444 (2017) doi.org/10.1016/B978-0-323-35214-7.00044-5.

14. AOAC, Official methods of analysis, 17th ed. (Association of Official Analytical Chemists International, Arlington, USA, 2000)

15. J. Gorelick-Feldman, W. Cohick, I. Raskin, Steroids 75, 632-637 (2010)

16. K.T. Erimbetov, O.V. Obvintseva, A.V. Fedorova, R.A. Zemlyanoy, A.G. Solovieva, Ukrainian Journal of Ecology 9(4), 651-656 (2019) 